\title{
Distinctive pattern of let-7 family microRNAs in aggressive carcinoma of the oral tongue in young patients
}

\author{
OHAD HILLY $^{1,2^{*}}$, NIR PILLAR $^{3 *}$, SAGIT STERN $^{1,2}$, YULIA STRENOV $^{4}$, \\ GIDEON BACHAR $^{1,2}$, NOAM SHOMRON ${ }^{3 *}$ and THOMAS SHPITZER ${ }^{1,2^{*}}$ \\ ${ }^{1}$ Department of Otolaryngology, Rabin Medical Center, Petah Tikva 49100; \\ Departments of ${ }^{2}$ Head and Neck Surgery and ${ }^{3}$ Cell and Developmental Biology, Sackler Faculty of Medicine, \\ Tel Aviv University, Tel Aviv 69978; ${ }^{4}$ Department of Pathology, Rabin Medical Center, Petah Tikva 49100, Israel
}

Received December 27, 2015; Accepted June 20, 2016

DOI: $10.3892 / \mathrm{ol} .2016 .4892$

\begin{abstract}
Oral cavity squamous cell carcinoma may be more aggressive at presentation and recurrence in young patients compared with older patients. Dysregulation of microRNAs (miRNAs or miRs) has been associated with the development and prognosis of oral cavity cancer. The present study investigated miRNA expression in carcinoma of the oral tongue in young patients. miRNA expression profiles were evaluated in formalin-fixed, paraffin-embedded samples of tumor and normal mucosa from 12 patients aged $<30$ years old with squamous cell carcinoma of the tongue. The levels of let-7f-5p, miR-30b-5p and let-7e-5p were upregulated in tumors $(\mathrm{P}<0.05)$. The expression of let-7f-5p was upregulated in non-aggressive tumors, while the expression of let-7e-5p was upregulated in aggressive tumors, compared with the corresponding normal tissue. Aggressive tumors had higher levels of let-7c, miR-130a-3p, miR-361-5p, miR-99a-5p, miR-29c-3p and let-7d-5p than non-aggressive tumors $(\mathrm{P}<0.05)$. The findings remained significant for let-7c upon false-discovery rate correction. An excellent correlation was noticed on validation of NanoString counts by quantitative polymerase chain reaction. The comparison with published findings in adults demonstrated a unique miRNA signature in young patients with aggressive disease. Aggressive oral cavity cancer in patients $<30$ years old is associated with a distinctive expression pattern of the let-7 family. Larger studies including direct comparison with older patients are warranted.
\end{abstract}

Correspondence to: Professor Noam Shomron, Department of Cell and Developmental Biology, Sackler Faculty of Medicine, Tel Aviv University, Ramat Aviv, Tel Aviv 69978, Israel

E-mail: nshomron@post.tau.ac.il

*Contributed equally

Key words: oral cavity cancer, young patients, squamous cell carcinoma, microRNA

\section{Introduction}

Squamous cell carcinoma (SCC) of the oral tongue is one of the most common types of head and neck cancer $(1,2)$. The incidence peaks in the sixth decade of life (1), and is clearly associated with ethylism and smoking (3). Previous studies suggest that, although the overall incidence of head and neck cancers is decreasing in the USA, the incidence of oral tongue carcinoma specifically is increasing in young patients $(2,4-7)$, particularly in white women (8). The factors responsible for this shift remain unclear. Unlike oropharyngeal cancer (malignancy of the tonsils or the base of tongue), whose rise in young patients has been attributed to malignant transformation subsequent to human papilloma virus infection $(9,10)$, no such association has been observed for oral tongue SCC.

The prognostic significance of age at diagnosis of oral tongue SCC is controversial. Garavello et al (11) demonstrated that patients younger than 40 years are at higher risk of recurrence and mortality than matched older patients. Other studies revealed that the prognostic disadvantage of young age may be limited to individuals with advanced, as opposed to early, disease at presentation (12) or with recurrent, as opposed to new-onset, disease (13). Accordingly, we previously reported that tongue carcinoma in patients $<30$ years old is more advanced at presentation, with significantly high rates of regional metastases and an increased risk of distant failure compared with patients $>30$ years (14). In addition, recurrent disease is aggressive, with a fatality rate of $100 \%$ (14). However, other authors noticed that clinical outcomes in young patients were similar to (15-18) or even better than (19-21) those in older patients.

MicroRNAs (miRNAs or miRs) are short, non-coding RNA molecules that regulate gene expression by controlling messenger (m)RNA translation (22). They are considered to play a role in normal biological processes, from cell growth to cell differentiation and death (22). miRNAs are dysregulated in various malignancies, and can act as both oncogenes and tumor suppressors $(22,23)$. In the head and neck, specific patterns of miRNA expression have been detected in cell lines and tumoral tissues from the hypopharynx, oral cavity, larynx, nasopharynx and salivary glands (23). Specific miRNAs that have been implicated in oral SCC cell lines and tumoral tissues include miR-211 (22), miR-184 (24), miR-137, miR-193a (25), 
miR-133a, miR-133b (26), miR-98 (27), Homo sapiens (hsa)-miR-15a (28), miR-126 (29) and miR-155 (30). Certain patterns of miRNA expression can also serve as prognostic markers. For example, high expression of miR-211 (22) and miR-21 $(31,32)$ was associated with poor prognosis in patients with oral carcinoma.

The aim of the present study was to identify specific miRNAs that are dysregulated in SCC of the oral tongue in young patients and to determine if these aberrations resemble known miRNA profiles in older patients.

\section{Materials and methods}

Study design and patient characteristics. The present study was approved by the Institutional Review Board of Rabin Medical Center (Petah Tikva, Israel), with waiver of informed consent.

The study group included 12 patients aged $\leq 30$ years with SCC of the oral tongue who underwent partial glossectomy with neck dissection at Rabin Medical Center between January 1996 and December 2013. The mean age of the patients was 22.5 years (range, 15-30 years), and 7 (58\%) patients were females. Two patients were smokers (1 and 6 packs/year, respectively), and none consumed alcohol. The mean follow-up time was 56 months.

At the time of diagnosis, 10 patients had advanced disease (stage 3-4), 9 had regional lymph node involvement and none had systemic metastases. All patients with advanced disease were also treated with radiotherapy, and 8 received adjuvant chemotherapy.

Five patients had a recurrence of the disease. The mean time from diagnosis to recurrence was 11.4 months (range, 5-16 months). All patients succumbed to the disease within a mean time of 18.4 months (range, 14-28 months). These patients were categorized as having aggressive disease, and the other 7 patients, without recurrence, were categorized as having non-aggressive disease. The mean follow-up time of the group with non-aggressive disease was 83 months (range, 24-132 months).

Sample collection. All tumors were diagnosed following partial glossectomy. For the present study, all available hematoxylin and eosin-stained slides were reviewed by a head and neck pathologist, and paraffin-embedded blocks of the most representative slides were used for RNA extraction. Samples of tumoral tissue and peritumoral normal tongue tissue were collected for each patient.

Total RNA was extracted from formalin-fixed, paraffin-embedded samples using RecoverAll Total Nucleic Acid Isolation kit, according to the manufacturer's protocol (Ambion, Life Technologies; Thermo Fisher Scientific, Inc. Waltham, MA, USA), and further purified with phenol-chloroform, followed by ethanol precipitation. The final RNA concentration and purity were measured with an ND-1000 spectrophotometer (NanoDrop Technologies; Thermo Fisher Scientific, Inc., Wilmington, DE, USA).

miRNA profiling. In total, $>800$ human miRNAs were profiled with the multiplexed nCounter ${ }^{\circledR}$ miRNA Expression Assay kit (NanoString Technologies, Seattle, WA, USA), according to the manufacturer's protocol. Briefly, 100 ng of total RNA was used as input material with $3 \mu \mathrm{l}$ of 3 -fold-diluted sample. A specific DNA tag was ligated onto the 3 ' end of each mature miRNA for exclusive identification for each of the miRNA species present in the sample. Tagging was performed in a multiplexed ligation reaction utilizing reverse complementary bridge oligonucleotides (NanoString Technologies). All hybridization reaction mixtures were incubated at $64^{\circ} \mathrm{C}$ for $18 \mathrm{~h}$. Excess tags were then removed, and the resulting material was hybridized with a panel of fluorescently labeled, bar-coded reporter probes, which were specific to the miRNA of interest. miRNAs abundance was quantified with the nCounter ${ }^{\circledR}$ Prep Station (NanoString Technologies) by counting the individual fluorescent barcodes and identifying the target miRNA molecules present in each sample. Each sample was normalized to the geometric mean of the top 100 highest expressed miRNAs. The mean value of the negative controls was set as the lower threshold for each sample; thus, when $\geq 50 \%$ of the value was equal to or lower than the lower threshold, the miRNA was excluded. Using these criteria, 93 miRNAs were identified to be eligible for subsequent analyses.

Quantitative polymerase chain reaction ( $q P C R$ ). qPCR was performed to validate the top candidates obtained with the nCounter ${ }^{\circledR}$ miRNA Expression Assay kit, according to the manufacturer's protocol (NanoString Technologies). The TaqMan Universal PCR Master Mix, Nno AmpErase UNG (Applied Biosystems; Thermo Fisher Scientific, Inc.) was used to test miRNA expression. PCR amplification and reading were performed with the StepOne ${ }^{\mathrm{TM}}$ Real-Time PCR System (Life Technologies; Thermo Fisher Scientific, Inc.) under the following conditions: $2 \mathrm{~min}$ at $50^{\circ} \mathrm{C}$ and $10 \mathrm{~min}$ at $95^{\circ} \mathrm{C}$, followed by 40 cycles of $95^{\circ} \mathrm{C}$ for $30 \mathrm{sec}$ and $60^{\circ} \mathrm{C}$ for $1 \mathrm{~min}$. Expression values were calculated using the comparative threshold cycle method (33), with normalization according to the total cellular RNA content.

Statistical analysis. Following data pre-processing and normalization, differential expression analysis was performed using nSolver ${ }^{\mathrm{TM}}$ Analysis Software (version 2.0; NanoString Technologies) and EXpression Analyzer and DisplayER version 6.06 (//acgt.cs.tau.ac.il/expander/). Student's $t$-test was used for statistical analysis. $\mathrm{P}<0.05$ was considered to indicate a statistically significant difference. P-values were adjusted according to the false-discovery rate (FDR).

\section{Results}

Comparisons. A total of 24 samples were analyzed, one from tumor and one from adjacent healthy tissue, for each patient. The miRNA results were compared between tumor and normal tissues, and between aggressive and non-aggressive tumors. No significant differences were identified in demographic characteristics or tumor stage between patients with aggressive and non-aggressive tumors $(\mathrm{P}=0.87$ and $\mathrm{P}=0.47$, respectively). Table I contains the significant differences in miRNA expression between the groups.

Tumors vs. adjacent normal tissues. Comparisons of the 12 tumor samples (aggressive and non-aggressive combined) 
Table I. miRNA expression by the studied groups.

\begin{tabular}{|c|c|c|c|}
\hline Comparison & miRNA & Fold-change & P-value \\
\hline \multicolumn{4}{|c|}{ Tumors vs. healthy tissue } \\
\hline \multirow[t]{4}{*}{ Upregulation } & let-7f-5p & 1.54 & $0.015^{\mathrm{a}}$ \\
\hline & $\operatorname{miR}-30 b-5 p$ & 1.49 & 0.039 \\
\hline & let-7e-5p & 1.27 & 0.040 \\
\hline & $\operatorname{miR}-26 a-5 p$ & 1.51 & 0.086 \\
\hline Downregulation & miR-185-5p & 0.78 & 0.060 \\
\hline \multicolumn{4}{|c|}{ Aggressive tumors vs. non-aggressive tumors } \\
\hline \multirow[t]{7}{*}{ Upregulation } & let-7c & 1.85 & $0.005^{\mathrm{a}}$ \\
\hline & $\operatorname{miR}-130 a-3 p$ & 1.39 & 0.008 \\
\hline & $\operatorname{miR}-361-5 p$ & 1.47 & 0.021 \\
\hline & let-7d-5p & 1.45 & 0.022 \\
\hline & miR-99a-5p & 1.67 & 0.025 \\
\hline & $\operatorname{miR}-29 c-3 p$ & 2.29 & 0.043 \\
\hline & let-7f-5p & 1.49 & 0.051 \\
\hline \multirow[t]{2}{*}{ Downregulation } & $\operatorname{miR}-181 a-5 p$ & 0.46 & 0.069 \\
\hline & let-7i-5p & 0.67 & 0.075 \\
\hline \multicolumn{4}{|c|}{ Normal tissue adjacent to aggressive vs. non-aggressive tumors } \\
\hline \multirow[t]{3}{*}{ Upregulation } & miR-107 & 1.86 & $0.010^{\mathrm{a}}$ \\
\hline & let-7f-5p & 1.72 & 0.016 \\
\hline & $\operatorname{miR}-30 b-5 p$ & 1.40 & 0.062 \\
\hline Downregulation & $\operatorname{miR}-34 a-5 p$ & 0.67 & 0.015 \\
\hline
\end{tabular}

${ }^{\text {a}}$ False-discovery rate-adjusted $\mathrm{P}<0.05 . \mathrm{miR} / \mathrm{miRNA}$, microRNA.

with the 12 normal-tissue samples revealed an upregulation of let-7f-5p, miR-30b-5p and let-7e-5p in the tumors $(\mathrm{P}<0.05)$; the difference for let-7f-5p remained significant following FDR correction. Stratification by disease aggressiveness yielded an upregulation of let-7f-5p in non-aggressive tumors and of let-7e-5p in aggressive tumors, compared with the corresponding healthy-tissue samples.

Aggressive vs. non-aggressive tumors. Fig. 1 represents the differential expression of the miRNAs with the highest expression levels, while Fig. 2 represents the expression of the significantly altered miRNAs in aggressive vs. non-aggressive tumors. There was a significant upregulation of let-7c, miR-130a-3p, miR-361-5p, miR-99a-5p, miR-29c-3p and let-7d-5p in the aggressive tumors $(P<0.05)$; the difference for let-7c remained significant after FDR correction. Additionally, the aggressive tumors exhibited downregulation of miR-181a-5p and let-7i-5p $(\mathrm{P}=0.06)$.

Normal tissues adjacent to aggressive vs. non-aggressive tumors. Normal tissues adjacent to aggressive tumors exhibited an upregulation of miR-107 and let-7f-5p $(\mathrm{P}<0.05)$; the difference for miR-107 remained significant after FDR correction. Normal tissues adjacent to non-aggressive tumors displayed a downregulation of miR-34a-5p $(\mathrm{P}<0.05)$.

NanoString counts were validated by qPCR (Fig. 2). A total of 4 samples were tested for let-7c expression and
4 were evaluated for miR-29c expression. A correlation of 0.93 was observed.

\section{Discussion}

The rising incidence of oral tongue SCC among young patients, combined with its weak association with known risk factors of other head and neck cancers (including smoking, ethylism and human papilloma virus infection) and its aggressiveness, have prompted researchers to seek molecular aberrations specific to the tumor in this age group (2,4-7). A high incidence of DNA ploidy abnormalities and microsatellite instability have been reported in young patients with tongue carcinoma $(34,35)$. Molecular markers observed to be similar in young and old patients include p53, p21, retinoblastoma protein and mouse double minute 2 homolog expression; presence of mismatch repair genes such as human mutL homolog 1 and human mutS homolog 2; loss of heterozygosity at the 3,9 and $17 \mathrm{p}$ regions; and high cell proliferation and angiogenesis index (34,36-39).

Numerous studies have reported that miRNA expression differs between cancer cells and healthy cells (22,28,40-45), although the exact mechanism by which each miRNA affects carcinogenesis is unclear. The present study sought, for the first time, to examine miRNA expression in oral cavity SCC in patients $<30$ years old. Comparisons of the tumor tissue with adjacent normal tissue revealed a significant upregulation of 
let-7f in tumor tissues, which remained significant after FDR correction. This increase was attributed mainly to overexpression of let-7f in non-aggressive tumors and overexpression of let-7e in aggressive tumors compared with normal tissues.

The tumoral upregulation of let-7f is in line with previous reports in older patients. Christensen et al (46) and Hui et al (40) demonstrated overexpression of let-7f in oropharyngeal cancer compared with oral cavity cancer and benign tonsillar tissue, and Cui et al (28) demonstrated overexpression of let-7f in oral cavity cancer compared with normal tissue. Tran et al (23) reported similar results in cell lines of head and neck SCC.

Given the aggressiveness of recurrent oral cavity cancer in young patients with a high mortality rate and increased risk of distant metastases (14), the present study analyzed molecular markers separately in aggressive and non-aggressive tumors. The results revealed an overexpression of let-7e in aggressive tumors compared with adjacent normal tissues (paired analysis) that was not evident in non-aggressive tumors. No dysregulation of let-7e was observed in any of the other studies of oral cavity cancer or other head and neck cancers, possibly suggesting a unique biology of aggressive tongue SCC in young patients.

A second (non-paired) evaluation of aggressive vs. non-aggressive tumors demonstrated an upregulation of let-7c, let-7d-5p, miR-99a-5p, miR-29c-3p, miR-130a-3p and miR-361-5p in the aggressive tumors, with let-7c remaining significant after FDR correction. Previous reports of miRNA dysregulation in oral cavity cancer that used normal tissue as the control demonstrated no aberration in let-7c and downregulation of let- $7 \mathrm{~d}$ in tumors $(28,41-43)$. By contrast, in the present study, both markers were upregulated. Additionally, our findings for mir-99 differed from a previous study, in which forced expression of miR-99 family members in head and neck SCC cell lines led to a reduction in cell proliferation and cell migration, and an increase in apoptosis (47). In addition, mir-29 was downregulated in that study (47) and in another study of nasopharyngeal carcinoma associated with miR-29c expression with increased sensitivity to cisplatin and inhibition of invasion and metastatic spread (48), in contrast to the present findings.

The literature on the role of miR-130a is inconsistent. Studies of ovarian and hepatocellular carcinoma tumors and head and neck SCC cell lines reported an association between miR-130a downregulation with reduced response/resistance to cisplatin (49) and docetaxel (50), respectively, and conversely, an association between miR-130a upregulation and increased cisplatin resistance (51). In liver cancer, downregulation of miR-130a was associated with poor prognosis (52). However, studies of cervical and esophageal cancer noticed that miR-130a upregulation was associated with tumor development and poor prognosis $(49,53)$, in line with our results in tumor vs. healthy cells. Similarly, in a study of 107 samples of oral cavity SCC, the copy number of mir-30b was frequently increased in advanced tumors, in correlation with hsa-miR-30b overexpression (54).

Previous studies evaluating let-7 expression in head and neck malignancies are summarized in Table II. The let-7 family of miRNAs are commonly considered tumor suppressors. They were originally discovered in the roundworm
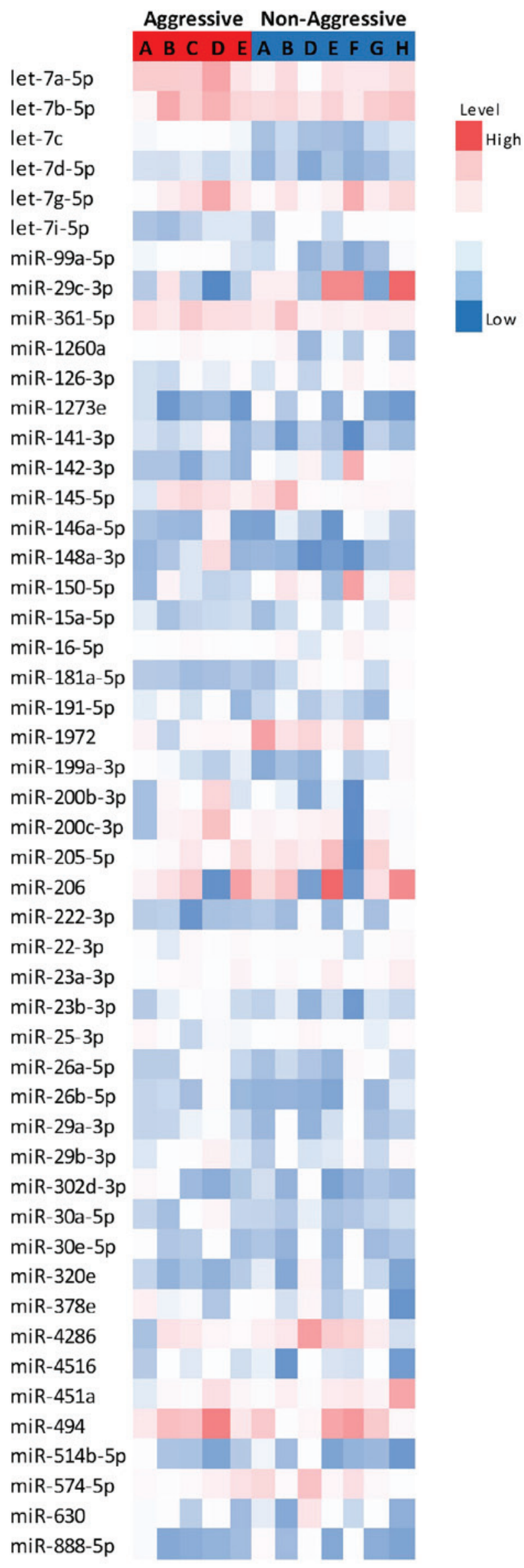

Figure 1. Heatmap of differentially expressed microRNAs (Z-scores of $\log _{2}$ values) in aggressive and non-aggressive tumors. Red indicates high expression and blue low expression. miR/miRNA, microRNA; hsa, Homo sapiens. 

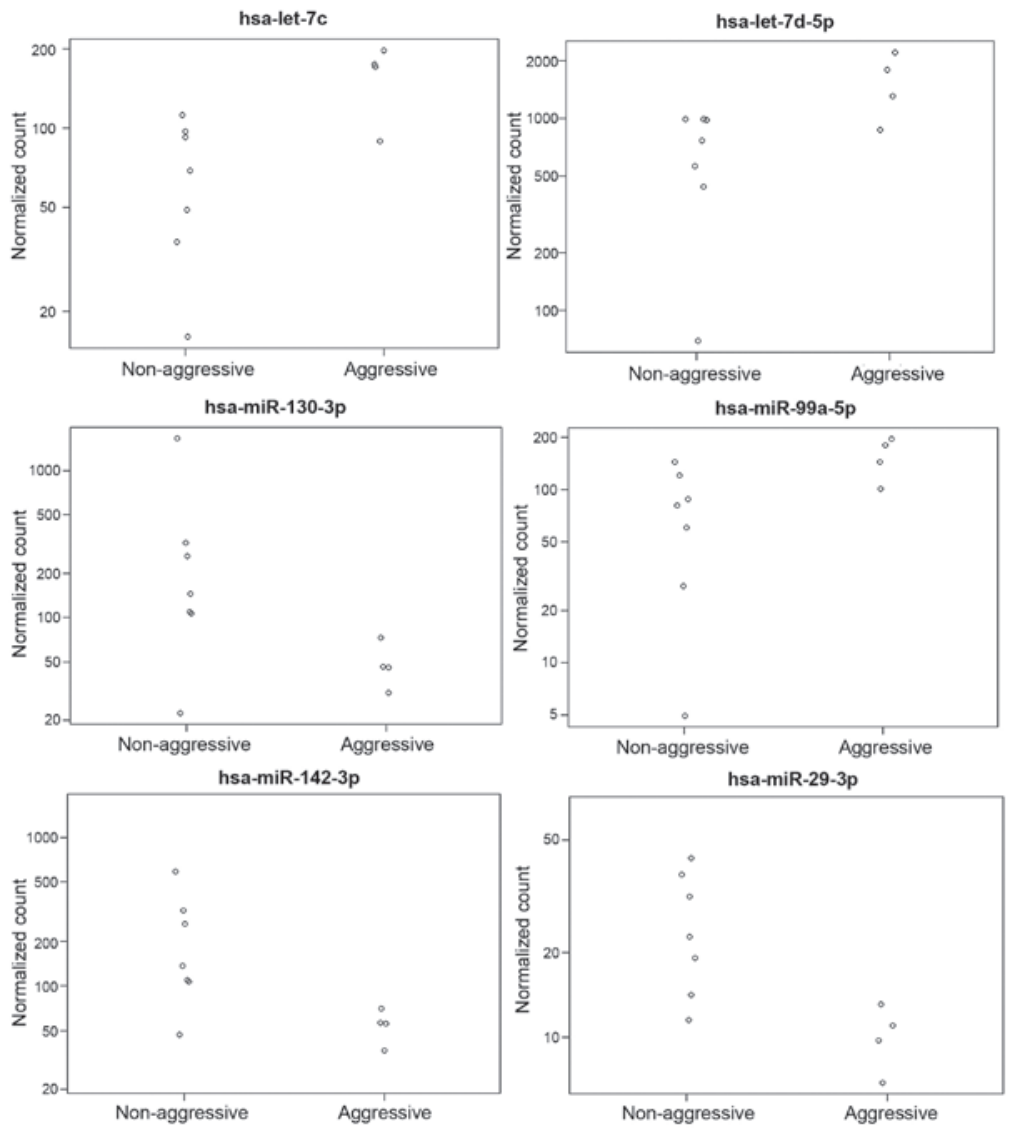

Figure 2. Plot of normalized counts for 6 microRNAs in 5 aggressive and 7 non-aggressive tumors. miR, microRNA.

Caenorhabditis elegans, a popular model in biology, where they were observed to be responsible for the development to the adult stage (55). let-7 miRNAs are dysregulated in lung, colorectal and gastric cancers (56-58). In lung cancer, reduced expression of let-7a was significantly associated with shortened postoperative survival, while its overexpression was significantly associated with inhibition of cancer cell growth (59). let-7 expression has also been associated with disease severity and survival in patients with head and neck cancer $(56,60)$.

Jakymiw et al (44) hypothesized that the let-7 family affects cancer biology by regulating the expression of Dicer, an RNase III-type enzyme present in almost all eukaryotes. Dicer is essential for RNA interference and miRNA pathway maturation (61). Dicer was observed to be overexpressed in prostate and lung adenocarcinomas $(62,63)$ and cervical cancers (53). Its overexpression (by 24-fold) in cell lines of head and neck cancer was associated with significantly reduced levels of let-7b. When the cancer cell lines were transfected with chemically synthesized let-7b, cell proliferation was inhibited by $\leq 83 \%$ (44).

Findings of reduced let-7 levels in the presence of increased expression of the RAS protein (59) have led to the hypothesis that let-7 may inhibit cancer growth via its effect on the RAS protein. Accordingly, in head and neck SCC, the presence of the RAS protein was significantly associated with poor prognosis and increased tumor size $(46,64)$. The inhibitory effect of let-7a in cancer development was further supported by findings of decreased let-7a levels in head and neck cancer and lymph node metastases (45).
Previous studies were inconsistent regarding the expression profiles of let-7a, let-7b, let-7c, let-7d and let-7f, with certain studies reporting overexpression while others reporting reduced expression in cancer (22-23,28,40-46). While the reduced expression of these miRNAs has provided a theoretical explanation to the mechanism by which cancer cells affect the RAS gene and protein, Dicer and HNC-TICS, no evidence has supported the upregulation of the let-7 family, which may explain the observed cell proliferation in head and neck cancers.

The majority of relevant studies conducted to date made no reference to patient age as a risk/contributory factor. Yu et al (45) compared miRNA expression in patients under and over the age of 50 years, and observed no difference between the groups.

The present study is affected by certain limitations. Oral cavity cancer in patients younger than 30 years of age is very uncommon $(1,2,4-7)$. Consequently, our samples are small and the statistical power is limited. The present study evaluated miRNA profiles in young patients and compared the results with published data, rather than comparing them directly with samples from older patients. Thus, methodological differences between the current study and previous studies may affect our assumptions.

To conclude, the current study presented the miRNA profile of oral cavity SCC in patients younger than 30 years of age. Our finding of overexpression of let- $7 \mathrm{f}$ in oral cavity cancer in young patients compared with adjacent normal tissue is in line with previous studies in older patients. However, further 
Table II. let-7 dysregulation in head and neck carcinoma.

\begin{tabular}{|c|c|c|c|c|c|c|c|c|c|}
\hline $\begin{array}{l}\text { Study, } \\
\text { author (ref) }\end{array}$ & Year & $\begin{array}{l}\text { Collected } \\
\text { samples }\end{array}$ & $\begin{array}{c}\text { Tissue } \\
\text { examined }\end{array}$ & $\mathrm{n}$ & Control & $\mathrm{n}$ & let-7 & Expression & $\begin{array}{l}\text { Age, } \\
\text { years }^{\text {a }}\end{array}$ \\
\hline $\begin{array}{l}\text { Chang } \\
\text { et al (22) }\end{array}$ & 2008 & Primary tumors & HNSCC & 4 & $\begin{array}{l}\text { Healthy tissue } \\
\text { (UPPP patients) }\end{array}$ & 4 & let-7i & Upregulated & 54 \\
\hline \multirow[t]{2}{*}{$\begin{array}{l}\text { Tran et al } \\
(23)\end{array}$} & 2010 & Cell lines & HNSCC & 9 & NA & & let-7a & Upregulated & NA \\
\hline & & & & & & & $\begin{array}{l}\text { let-7b } \\
\text { let-7c } \\
\text { let-7d } \\
\text { let-7f }\end{array}$ & $\begin{array}{l}\text { Upregulated } \\
\text { Upregulated } \\
\text { Upregulated } \\
\text { Upregulated }\end{array}$ & \\
\hline \multirow[t]{2}{*}{$\begin{array}{l}\text { Cui et al } \\
(28)\end{array}$} & 2014 & NA & OCSCC & 17 & $\begin{array}{l}\text { Healthy } \\
\text { controls }\end{array}$ & 3 & let-7a & Upregulated & NA \\
\hline & & & & & & & let-7f & Upregulated & \\
\hline \multirow[t]{4}{*}{$\begin{array}{l}\text { Christensen } \\
\text { et al (46) }\end{array}$} & 2009 & $\begin{array}{l}\text { Whole blood and } \\
\text { buccal cells }\end{array}$ & OCSCC & 10 & $\begin{array}{l}\text { Pharyngeal } \\
\text { cancer }\end{array}$ & 4 & let-7a & Downregulated & NA \\
\hline & & & & & & & let-7c & Downregulated & \\
\hline & & & & & & & let-7d & Downregulated & \\
\hline & & & & & & & let-7f & Downregulated & \\
\hline \multirow[t]{2}{*}{$\begin{array}{l}\text { Hui et al } \\
(40)\end{array}$} & 2013 & FFPE & $\begin{array}{l}\text { Oropharyngeal } \\
\text { SCC }\end{array}$ & 88 & Tonsillectomy & 7 & let-7f & Upregulated & $55 \pm 11$ \\
\hline & & & & & & & let- $7 \mathrm{~g}$ & Upregulated & \\
\hline \multirow[t]{2}{*}{$\begin{array}{l}\text { Ricieri Brito } \\
\text { et al }(41)\end{array}$} & 2010 & $\begin{array}{l}\text { Primary tumors } \\
\text { and whole blood }\end{array}$ & OCSCC & 20 & $\begin{array}{l}\text { Self-control- } \\
\text { healthy tissue }\end{array}$ & & let-7a & $\begin{array}{l}\text { Downregulated } \\
(n=18)\end{array}$ & $\begin{array}{c}57 \\
(37-90)\end{array}$ \\
\hline & & & & & & & let-7a & $\begin{array}{l}\text { Upregulated } \\
(n=13)\end{array}$ & \\
\hline $\begin{array}{l}\text { Chang } \\
\text { et al (42) }\end{array}$ & 2011 & Cell lines & OCSCC & NA & $\begin{array}{l}\text { Human normal } \\
\text { keratinocyte cells }\end{array}$ & NA & let-7d & Downregulated & NA \\
\hline \multirow[t]{3}{*}{$\begin{array}{l}\text { Maclellan } \\
\text { et al }(43)\end{array}$} & 2012 & Serum samples & $\mathrm{CIS}+\mathrm{OCSCC}$ & 30 & $\begin{array}{l}\text { Non-cancer } \\
\text { patients serum }\end{array}$ & 26 & let-7a & Upregulated & $50-93$ \\
\hline & & & & & & & let-7b & Upregulated & \\
\hline & & & & & & & let7-d & Downregulated & \\
\hline $\begin{array}{l}\text { Jakymiw } \\
\text { et al (44) }\end{array}$ & 2010 & Cell lines & HNSCC & 6 & $\begin{array}{l}\text { Healthy } \\
\text { gingival } \\
\text { cells }\end{array}$ & NA & let-7b & Downregulated & NA \\
\hline \multirow[t]{2}{*}{$\begin{array}{l}\text { Yu et al } \\
(45)\end{array}$} & 2011 & Primary tumors & $\begin{array}{l}\text { Head and neck } \\
\text { cancer }\end{array}$ & 107 & $\begin{array}{l}\text { Self-control- } \\
\text { healthy tissue }\end{array}$ & & let-7a & Downregulated & NA \\
\hline & & & metastases & 50 & No metastases & 57 & let-7a & Downregulated & \\
\hline \multirow[t]{3}{*}{$\begin{array}{l}\text { Current } \\
\text { study }\end{array}$} & 2015 & Primary tumors & OCSCC & 12 & $\begin{array}{l}\text { Self-control- } \\
\text { healthy tissue }\end{array}$ & 12 & $\begin{array}{l}\text { let-7f } \\
\text { let-7e }\end{array}$ & $\begin{array}{l}\text { Upregulated } \\
\text { Upregulated }\end{array}$ & $15-30$ \\
\hline & & & Aggressive & 5 & Non aggressive & 7 & let-7c & Upregulated & \\
\hline & & & OCSCC & & $\mathrm{OCSCC}$ & & let-7d & Upregulated & \\
\hline
\end{tabular}

${ }^{a}$ All ages are ranges, with the exception of Hui et al, which is the mean age. CIS, carcinoma in situ; FFPE, formalin-fixed paraffin-embedded; HNSCC, head and neck squamous cell carcinoma; NA, not available; OCSCC, oral cavity squamous cell carcinoma; SCC, squamous cell carcinoma; UPPP, uvulopalatopharyngoplasty.

stratification of the tumors by aggressiveness revealed that let-7f was overexpressed in non-aggressive tumors, whereas the aggressive tumors had a distinctive miRNA expression pattern, with upregulation of let-7e (compared with normal tissue) as well as let-7c and let-7d (compared with non-aggressive tumors).
These findings may aid the prognosis of oral cavity tumors in young patients, which may be very aggressive and exhibit a high mortality rate. Further studies with direct comparison with tissues from older patients are warranted to validate the prognostic role of these miRNA aberrations in oral cavity SCC. 


\section{Acknowledgements}

The present study was supported by a research grant from the Schauder Foundation, Sackler School of Medicine, Tel Aviv University (Tel Aviv, Israel; grant no. 32003156000). The present study was based on an abstract presented at The Annual Meeting of The Israeli Society of Otolaryngology, Head and Neck Surgery on March 9-12, 2016 in Eilat, Israel (available at www.entisrael.com/wp content/uploads/2016/01/ENT2016_ BookProgram.pdf).

\section{References}

1. Horner MJ, Ries LAG, Krapcho M, Neyman N, Aminou R, Howlader N, et al (eds): SEER Cancer Statistics Review, 19752006. National Cancer Institute, Bethesda, MD. seer.cancer. gov/csr/1975_2006/, based on November 2008 SEER data submission, posted to the SEER web site, 2009. Accessed on June 27, 2016.

2. Cancer Research UK: Oral cancer - UK incidence statistics. www.cancerresearchuk.org/health-professional/cancerstatistics/statistics-by-cancer-type/oral-cancer/incidence. Accessed on June 27, 2016

3. Mashberg A, Boffetta P, Winkelman R and Garfinkel L: Tobacco smoking, alcohol drinking, and cancer of the oral cavity and oropharynx among U.S. veterans. Cancer 72 : 1369-1375, 1993.

4. Myers JN, Elkins T, Roberts D and Byers RM: Squamous cell carcinoma of the tongue in young adults: Increasing incidence and factors that predict treatment outcomes. Otolaryngol Head Neck Surg 122: 44-51, 2000.

5. Annertz K, Anderson H, Biörklund A, Möller T, Kantola S, Mork J, Olsen JH and Wennerberg J: Incidence and survival of squamous cell carcinoma of the tongue in Scandinavia, with special reference to young adults. Int J Cancer 101: 95-99, 2002.

6. Shiboski $\mathrm{CH}$, Schmidt BL and Jordan RC: Tongue and tonsil carcinoma: Increasing trends in the U.S. population ages 20-44 years. Cancer 103: 1843-1849, 2005.

7. Brown LM, Check DP and Devesa SS: Oral cavity and pharynx cancer incidence trends by subsite in the United States: Changing gender patterns. J Oncol 2012: 649498, 2012.

8. Patel SC, Carpenter WR, Tyree S, Couch ME, Weissler M, Hackman T, Hayes DN, Shores C and Chera BS: Increasing incidence of oral tongue squamous cell carcinoma in young white women, age 18 to 44 years. J Clin Oncol 29: 1488-1494, 2011.

9. Mork J, Lie AK, Glattre E, Hallmans G, Jellum E, Koskela P, Møller B, Pukkala E, Schiller JT, Youngman L, et al: Human papillomavirus infection is a risk factor for squamous-cell carcinoma of the head and neck. N Engl J Med 344: 1125-1131, 2001.

10. Pintos J, Black MJ, Sadeghi N, Ghadirian P, Zeitouni AG, Viscidi RP, Herrero R, Coutlée F and Franco EL: Human papillomavirus infection and oral cancer: A case-control study in Montreal, Canada. Oral Oncol 44: 242-250, 2008

11. Garavello W, Spreafico R and Gaini RM: Oral tongue cancer in young patients: A matched analysis. Oral Oncol 43: 894-897, 2007.

12. Park JO, Sun DI, Cho KJ, Joo YH, Yoo HJ and Kim MS: Clinical outcome of squamous cell carcinoma of the tongue in young patients: A stage-matched comparative analysis. Clin Exp Otorhinolaryngol 3: 161-165, 2010.

13. Mallet Y, Avalos N, Le Ridant AM, Gangloff P, Moriniere S, Rame JP, Poissonnet G, Makeieff M, Cosmidis A, Babin E, et al: Head and neck cancer in young people: A series of $52 \mathrm{SCCs}$ of the oral tongue in patients aged 35 years or less. Acta Otolaryngol 129: 1503-1508, 2009.

14. Hilly O, Shkedy Y, Hod R, Soudry E, Mizrachi A, Hamzany Y, Bachar $G$ and Shpitzer T: Carcinoma of the oral tongue in patients younger than 30 years: Comparison with patients older than 60 years. Oral Oncol 49: 987-990, 2013.

15. Friedlander PL, Schantz SP, Shaha AR, Yu G and Shah JP: Squamous cell carcinoma of the tongue in young patients: A matched-pair analysis. Head Neck 20: 363-368, 1998.
16. Siegelmann-Danieli N, Hanlon A, Ridge JA, Padmore R, Fein DA and Langer CJ: Oral tongue cancer in patients less than 45 years old: Institutional experience and comparison with older patients. J Clin Oncol 16: 745-753, 1998.

17. Pitman KT, Johnson JT, Wagner RL and Myers EN: Cancer of the tongue in patients less than forty. Head Neck 22: 297-302, 2000.

18. Popovtzer A, Shpitzer T, Bahar G, Marshak G, Ulanovski D and Feinmesser R: Squamous cell carcinoma of the oral tongue in young patients. Laryngoscope 114: 915-917, 2004.

19. Davidson BJ, Root WA and Trock BJ: Age and survival from squamous cell carcinoma of the oral tongue. Head Neck 23: 273-279, 2001.

20. Lee CC, Ho HC, Chen HL, Hsiao SH, Hwang JH and Hung SK: Squamous cell carcinoma of the oral tongue in young patients: A matched-pair analysis. Acta Otolaryngol 127: 1214-1217, 2007.

21. Udeabor SE, Rana M, Wegener G, Gellrich NC and Eckardt AM: Squamous cell carcinoma of the oral cavity and the oropharynx in patients less than 40 years of age: A 20 -year analysis. Head Neck Oncol 4: 28, 2012.

22. Chang KW, Liu CJ, Chu TH, Cheng HW, Hung PS, Hu WY and Lin SC: Association between high miR-211 microRNA expression and the poor prognosis of oral carcinoma. J Dent Res 87: 1063-1068, 2008

23. Tran N, O'Brien CJ, Clark J and Rose B: Potential role of micro-RNAs in head and neck tumorigenesis. Head Neck 32: 1099-1111, 2010.

24. Wong TS, Liu XB, Wong BY, Ng RW, Yuen AP and Wei WI: Mature miR-184 as potential oncogenic microRNA of squamous cell carcinoma of tongue. Clin Cancer Res 14: 2588-2592, 2008.

25. Kozaki K, Imoto I, Mogi S, Omura K and Inazawa J: Exploration of tumor-suppressive microRNAs silenced by DNA hypermethylation in oral cancer. Cancer Res 68: 2094-2105, 2008.

26. Wong TS, Liu XB, Chung-Wai Ho A, Po-Wing Yuen A, Wai-Man $\mathrm{Ng} \mathrm{R}$ and Ignace Wei W: Identification of pyrovate kinase type $\mathrm{M} 2$ as potential oncoprotein in squamous cell carcinoma of tongue through microRNA profiling. Int J Cancer 123: 251-257, 2008.

27. Hebert C, Norris K, Scheper MA, Nikitakis N and Sauk JJ: High mobility group A2 is a target for miRNA-98 in head and neck squamous cell carcinoma. Mol Cancer 6: 5, 2007.

28. Cui J, Li D, Zhang W, Shen L and Xu X: Bioinformatics analyses combined microarray identify the deregulated microRNAs in oral cancer. Oncol Lett 8: 218-222, 2014.

29. Yang X, Wu H and Ling T: Suppressive effect of microRNA-126 on oral squamous cell carcinoma in vitro. Mol Med Rep 10: 125-130, 2014.

30. Shi LJ, Zhang CY, Zhou ZT, Ma JY, Liu Y, Bao ZX and Jiang WW: MicroRNA-155 in oral squamous cell carcinoma: Overexpression, localization, and prognostic potential. Head Neck 37: 970-976, 2015.

31. Li J, Huang H, Sun L, Yang M, Pan C, Chen W, Wu D, Lin Z, Zeng C, Yao Y, et al: MiR-21 indicates poor prognosis in tongue squamous cell carcinoma as an apoptosis inhibitor. Clin Cancer Res 15: 3998-4008, 2009.

32. Hedbäck N, Jensen DH, Specht L, Fiehn AM, Therkildsen MH, Friis-Hansen L, Dabelsteen E and von Buchwald C: MiR-21 expression in the tumor stroma of oral squamous cell carcinoma: An independent biomarker of disease free survival. PLoS One 9: e95193, 2014

33. Kanno J, Aisaki KI, Igarashi K, Nakatsu N, Ono A, Kodama Y and Nagao T: "Per cell" normalization method for mRNA measurement by quantitative PCR and microarrays. BMC Genomics 7: 64, 2006.

34. Wang Y, Irish J, MacMillan C, Brown D, Xuan Y, Boyington C, Gullane P and Kamel-Reid S: High frequency of microsatellite instability in young patients with head-and-neck squamous-cell carcinoma: Lack of involvement of the mismatch repair genes hMLH1 AND hMSH2. Int J Cancer 93: 353-360, 2001.

35. Santos-Silva AR, Ribeiro AC, Soubhia AM, Miyahara GI, Carlos R, Speight PM, Hunter KD, Torres-Rendon A, Vargas PA and Lopes MA: High incidences of DNA ploidy abnormalities in tongue squamous cell carcinoma of young patients: An international collaborative study. Histopathology 58: 1127-1135, 2011.

36. Atula $S$, Grénman R, Laippala $P$ and Syrjänen $S$ : Cancer of the tongue in patients younger than 40 years. A distinct entity? Arch Otolaryngol Head Neck Surg 122: 1313-1319, 1996.

37. Jin YT, Myers J, Tsai ST, Goepfert H, Batsakis JG and el-Naggar AK: Genetic alterations in oral squamous cell carcinoma of young adults. Oral Oncol 35: 251-256, 1999. 
38. Regezi JA, Dekker NP, McMillan A, Ramirez-Amador V, Meneses-Garcia A, Ruiz-Godoy Rivera LM, Chrysomali E and $\mathrm{Ng}$ IO: $\mathrm{p} 53, \mathrm{p} 21, \mathrm{Rb}$, and MDM2 proteins in tongue carcinoma from patients $<35$ versus $>75$ years. Oral Oncol 35: 379-383, 1999.

39. Benevenuto TG, Nonaka CF, Pinto LP and de Souza LB: Immunohistochemical comparative analysis of cell proliferation and angiogenic index in squamous cell carcinomas of the tongue between young and older patients. Appl Immunohistochem Mol Morphol 20: 291-297, 2012.

40. Hui AB, Lin A, Xu W, Waldron L, Perez-Ordonez B, Weinreb I, Shi W, Bruce J, Huang SH, O'Sullivan B, et al: Potentially prognostic miRNAs in HPV-associated oropharyngeal carcinoma. Clin Cancer Res 19: 2154-2162, 2013.

41. Ricieri Brito JA, Gomes CC, Santos Pimenta FJ, Barbosa AA, Prado MA, Prado VF, Gomez MV and Gomez RS: Reduced expression of mirl5a in the blood of patients with oral squamous cell carcinoma is associated with tumor staging. Exp Ther Med 1: 217-221, 2010

42. Chang CJ, Hsu CC, Chang CH, Tsai LL, Chang YC, Lu SW, $\mathrm{Yu} \mathrm{CH}$, Huang HS, Wang JJ, Tsai $\mathrm{CH}$, et al: Let-7d functions as novel regulator of epithelial-mesenchymal transition and chemoresistant property in oral cancer. Oncol Rep 26: 1003-1010, 2011.

43. Maclellan SA, Lawson J, Baik J, Guillaud M, Poh CF and Garnis C: Differential expression of miRNAs in the serum of patients with high-risk oral lesions. Cancer Med 1: 268-274, 2012.

44. Jakymiw A, Patel RS, Deming N, Bhattacharyya I, Shah P, Lamont RJ, Stewart CM, Cohen DM and Chan EK: Overexpression of dicer as a result of reduced let-7 MicroRNA levels contributes to increased cell proliferation of oral cancer cells Genes Chromosomes Cancer 49: 549-559, 2010.

45. Yu CC, Chen YW, Chiou GY, Tsai LL, Huang PI, Chang CY, Tseng LM, Chiou SH, Yen SH, Chou MY, et al: MicroRNA let-7a represses chemoresistance and tumorigenicity in head and neck cancer via stem-like properties ablation. Oral Oncol 47: 202-210, 2011.

46. Christensen BC, Moyer BJ, Avissar M, Ouellet LG, Plaza SL, McClean MD, Marsit CJ and Kelsey KT: A let-7 microRNA-binding site polymorphism in the KRAS 3'UTR is associated with reduced survival in oral cancers. Carcinogenesis 30: 1003-1007, 2009.

47. Chen Z, Jin Y, Yu D, Wang A, Mahjabeen I, Wang C, Liu X and Zhou X: Down-regulation of the microRNA-99 family members in head and neck squamous cell carcinoma. Oral Oncol 48: 686-691, 2012

48. Zhang JX, Qian D, Wang FW, Liao DZ, Wei JH, Tong ZT, Fu J, Huang XX, Liao YJ, Deng HX, et al: MicroRNA-29c enhances the sensitivities of human nasopharyngeal carcinoma to cisplatin-based chemotherapy and radiotherapy. Cancer Lett 329: 91-98, 2013

49. Zhang X, Huang L, Zhao Y and Tan W: Downregulation of miR-130a contributes to cisplatin resistance in ovarian cancer cells by targeting X-linked inhibitor of apoptosis (XIAP) directly. Acta Biochim Biophys Sin (Shanghai) 45: 995-1001, 2013.
50. Dai Y, Xie CH, Neis JP, Fan CY, Vural E and Spring PM: MicroRNA expression profiles of head and neck squamous cell carcinoma with docetaxel-induced multidrug resistance. Head Neck 33: 786-791, 2011.

51. Xu N, Shen C, Luo Y, Xia L, Xue F, Xia Q and Zhang J: Upregulated miR-130a increases drug resistance by regulating RUNX3 and Wnt signaling in cisplatin-treated HCC cell. Biochem Biophys Res Commun 425: 468-472, 2012.

52. Yang J, Han S, Huang W, Chen T, Liu Y, Pan S and Li S: A meta-analysis of microRNA expression in liver cancer. PLoS One 9: e114533, 2014.

53. He L, Wang HY, Zhang L, Huang L, Li JD, Xiong Y, Zhang MY, Jia WH, Yun JP, Luo RZ and Zheng M: Prognostic significance of low DICER expression regulated by miR-130a in cervical cancer. Cell Death Dis 5: e1205, 2014.

54. Shao C, Yu Y, Yu L, Pei Y, Feng Q, Chu F, Fang Z and Zhou Y: Amplification and up-regulation of microRNA-30b in oral squamous cell cancers. Arch Oral Biol 57: 1012-1017, 2012.

55. Reinhart BJ, Slack FJ, Basson M, Pasquinelli AE, Bettinger JC, Rougvie AE, Horvitz HR and Ruvkun G: The 21-nucleotide let-7 RNA regulates developmental timing in Caenorhabditis elegans. Nature 403: 901-906, 2000.

56. Takamizawa J, Konishi H, Yanagizawa K, Tomida S, Osada $H$, Endoh H, Harano T, Yatabe Y, Nagino M, Nimura Y, et al: Reduced expression of the let-7 microRNAs in human lung cancers in association with shortened postoperative survival. Cancer Res 64: 3753-3756, 2004.

57. Akao Y, Nakagawa Y and Naoe T: Let-7 microRNA functions as a potential growth suppressor in human colon cancer cells. Biol Pharm Bull 29: 903-906, 2006.

58. Zhang B, Pan X, Cobb GP and Anderson TA: MicroRNAs as oncogenes and tumor suppressors. Dev Biol 302: 1-12, 2007.

59. Lu J, Getz G, Miska EA, Alvarez-Saavedra E, Lamb J, Peck D, Sweet-Cordero A, Ebert BL, Mak RH, Ferrando AA, et al: MicroRNA expression profiles classify human cancers. Nature 435: 834-838, 2005

60. Johnson SM, Grosshans H, Shingara J, Byrom M, Jarvis R, Cheng A, Labourier E, Reinert KL, Brown D and Slack FJ: RAS is regulated by the let-7 MicroRNA family. Cell 120: 635-647, 2005

61. Rana TM: Illuminating the silence: Understanding the structure and function of small RNAs. Nat Rev Mol Cell Biol 8: 23-36, 2007.

62. Chiosea S, Jelezcova E, Chandran U, Acquafondata M, McHale T, Sobol RW and Dhir R: Up-regulation of dicer, a component of the MicroRNA machinery, in prostate adenocarcinoma. Am J Pathol 169: 1812-1820, 2006.

63. Chiosea S, Jelezcova E, Chandran U, Luo J, Mantha G, Sobol RW and Dacic S: Overexpression of Dicer in precursor lesions of lung adenocarcinoma. Cancer Res 67: 2345-2350, 2007.

64. Perez-Ordoñez B, Beauchemin M and Jordan RC. Molecular biology of squamous cell carcinoma of the head and neck. J Clin Pathol 59: 445-453, 2006. 